\title{
DIONNE BRAND AND ALANIS OBOMSAWIN: POLYPHONY IN THE POETICS OF RESISTANCE
}

\author{
Maria Lúcia Milléo Martins \\ Universidade Federal de Santa Catarina
}

\section{Abstract}

Activist artists Dionne Brand and Alanis Obomsawin have much in common in their poetics of resistance. Brand's writings and documentaries explore issues of displacement, race, gender, and colonialism, revealing a constant determination in giving voice to what was silenced or marginalized by the dominant culture. Similarly, Obomsawin's documentaries show a long commitment to the history of aboriginal people, reclaiming their sovereignty of voice. Making use of polyphony, these two artists contest hegemonic discourses and a nationalist aesthetic that either ignores or appropriates difference. This study discusses the implications of polyphony in Brand's poetry and two documentaries, Sisters in the Struggle and Long Time Comin', and in Obomsawin's documentaries, Kanehsatake: 270 Years of Resistance and Rocks at Whiskey Trench. All evidences demonstrate fine specimens of applied poetics, faithful to their ethics of resistance.

Keywords: Dionne Brand, Alanis Obomsawin, poetics of resistance, polyphony.

Dionne Brand, Caribbean-Canadian writer and film-maker, and Alanis Obomsawin, Aboriginal-Canadian filmmaker and musician,

\begin{tabular}{|l|l|l|l|l|}
\hline Ilha do Desterro & Florianópolis & no 56 & p. 151-164 & jan./jun. 2009 \\
\hline
\end{tabular}


have a long repertoire in the poetics of resistance. Since the beginning of her career, Brand has been an activist in various fronts against discriminations of race, gender, and alien cultures of immigrants and aboriginals. She resists the myth of origin of Canada and all other forms of perpetuating colonialism and hegemony in the present. For her, only the many voices of difference emerging in the country that "see the imagination as transformative," can lead out of the damages of the dominant discourse. ${ }^{1}$ Obomsawin, on her turn, began her career as a singer, writer and storyteller, voicing the cultural legacy of her Abenaki origin. After engaging cinema and joining the National Film Board, she has directed over 30 documentaries on issues related to the history of aboriginal peoples in Canada. Her films incite serious reflection on the First Nations' long resistance holding on to their lands and cultural traditions. Correspondences between the works of these memorable women are many. This study particularly observes how their poetics of resistance privilege plurality of voices, allowing subjects to speak for themselves. Evidences for this are selected from Brand's poetry and two documentaries: Sisters in the Struggle and Long Time Comin'; and from Obomsawin's documentaries: Kanehsatake: 270 Years of Resistance and Rocks at Whiskey Trench. As Obomsawin says, "the camera can speak, but it can also listen, ${ }^{2}$ and so does poetry.

The term "poetics" is here used in its applied sense, as artistic and political devices used to articulate difference and resistance or, as Fred Wah puts it, "to initiate movement and change" (51). Many tools serve the purpose of this kind of poetics, among them double-voicing, irony, mimicry, silence, hybrid discourse, and polyphony. In the Bakhtinian sense of the word, polyphony which includes diversity of voices and points of view, promotes dialogism, disturbing the pretentious unity of dominant discourses. As Wah observes,

in opposition to a nationalistic aesthetic that continually attempts to expropriate difference into its own consuming narrative, writers of colour and Aboriginal writers gain 
significant social empowerment by engaging in dialogues that relocate the responsibility for their own subjectivity within themselves (76).

In both cases of Brand and Obomsawin, subjectivity is in close connection with sense of community. In Brand this extends from the African diaspora, Caribbean roots, to a particular identification with the saga of black women; in Obomsawin, from an affiliation with the history of First Nations in Canada at large to links with specific aboriginal cultures she has chosen to depict.

Be it in representations of communities or individuals, Brand and Obomsawin do not assume an authoritative position of speaking for them, but prefer instead to let them speak for themselves. Once invited to collaborate on a film about racism, Brand declined the task for disagreeing with the proposed agenda, and justifying: "Look, if you ever want to do something about Black women from their point of view, about their life, about their history, there's lots to do, if you want that then call me." ${ }^{3}$ Brand's documentaries Sisters in the Struggle and Long Time Comin' are resultant from this perspective. ${ }^{4}$ Similarly, when consulted by members of NFB (National Film Board) about a film on an Indian reserve they were about to make in the sixties, Obomsawin's advice was: "Let our people speak." As Robert Verrall remembers, she then pointed out that, "for the most part, NFB films about Aboriginal peoples had been platforms for whites voicing the sentiments of white society" (9).

In Brand's poetics of resistance, the performative questions official histories, giving testimony to what was silenced or excluded. In poetry, this is shown from early collections to more recent ones. In Primitive Offensive, her third book, she appropriates a traditional European poetic form-the cantos-to evoke her African ancestry, heroes and hurts of slavery, and to witness contemporary diaspora. The dialogic character of her cantos explores ways of speaking not only "about" or "for" her people, but "to" them. 
In "Canto VI," for example, the poet talks to different black people displaced in contemporary Europe, as memory reenacts a long legacy of racism and violence.

you, in the square,

you in the square of Koln

in the square before that huge destructive cathedral

what are you doing there

playing a drum

you, who pretend not to recognize me

you worshipper of insolubles

I know you slipped, tripped on your tie

the one given to you at the bazaar where

they auctioned off your beard

you lay in white sheets for some years

then fled

to the square

grabbing these colors, red, green, gold like

some bright things

to tie your head and bind you to some place

grabbing this flute

this drum

this needle and syringe

this far from Lagos,

and you, the other day in Vlissengen,

I was shocked to see you

in your bathing suit

on that white beach in Holland

what were you doing there

and again the other night

I saw you in Paris near St. Michel Metro

dressed like that 
dressed as if you were lost

[...] (30)

"You" here both particularizes the drama of each individual-"you, in the square" and, later, "Madagascar woman," "Senegal man"—and binds them to a collective experience. The absence of answers on the part of these people, for only the poet speaks to them, is replaced by the voices of their bodies evoking their sagas of displacement. These voices interweave with others from the past as the poet not only witnesses but intervenes in history:

I went to Paris

to where shortarsed Napoleon said, 'get that nigger Touissaint,' Toussaint, who was too gentle, He should have met Dessalines,

I went there to start a war

for the wars we never started

to burn the Code Noir

on the Champs Elysees. (32)

Chronicles of the Hostile Sun and No Language is Neutral, subsequent books, consolidate Brand's commitment to resistance. With documentary precision, the former makes a lyrical counter-offensive to the invasion of Grenada; the latter radically confronts the "language of normalcy and affirmation" that speaks for the whole race. ${ }^{5}$ Especially in portraits of women, Brand gives voice to what was silenced. "In "Amelia," a tribute to the Caribbean grandmother, Brand recreates her last days of life in an anchor of confinements. Amelia's silence is translated in an imaginative view of her inner world, and the circumstances that made her lose her voice. Similarly, the poem "Blues Spiritual for Mammy Prater," motivated by the photograph of a centenarian ex-slave, acts out a whole life of silent preparation for this moment: 
she waited until it suited her

to take this photograph and to put those eyes in it. in the hundred and fifteen years which it took her to wait for this photograph she perfected this pose she sculpted it over a shoulder of pain,

a thing like despair which she never called

this name for she would not have lasted

the fields, the ones she ploughed

on the days that she was a mule, left

their etching on the gait of her legs

deliberately and unintentionally

she waited, not always silently, not always patiently,

for this self-portrait

by the time she sat in her black dress, white collar, white handkerchief, her feet had turned to marble, her heart burnished red,

and her eyes. (16-32)

More than verbalizing what was silenced, the poet ironically reverses the passive role of posing to the feat of self-portrait. Brand's concern in not simply speaking for those who were silenced but attributing to them some dignity of agency is also found in other portraits like the ones of revolutionary women in defense of Grenada.

Brand's poetics largely demystifies the opacity of language, and assumptions of universal subjectivity, showing that "each sentence realized or / dreamed jumps like a pulse with history and takes a / side"("No Language is Neutral," poem 13, 15-17). As Jason Wiens notes about "No Language is Neutral," "with its polyphonic collision of socially stratified versions of world English," Brand opposes the idea of a dominant language, naturalized and monophonic (82-83). Her use of various forms of the demotic and "code-switching" is a consistent way of doing this, as the self-portrait of the arrival in Canada illustrates: 
Is steady trembling I trembling when they ask me my name and say I too black for it. Is steady hurt I feeling when old talk bleed, the sea don't have branch you know darling...

$\ldots$ and nobody wouldn't

vex if you miss the train, calling Spadina Spadeena until I listen good for what white people call it, saying I coming just to holiday to the immigration officer when me and the son-of-a bitch know I have labourer mark all over my face. ("No Language is Neutral," poem 8, 1-4, 6-11)

In recreating the confrontation with the dominant foreign language and racism, Brand's voice echoes others in similar situations. Wiens points out that, in framing the utterances of the privileged position within free indirect discourse ("too black for it," "you know darling"), Brand's text "at once relates a personal narrative of debasement and subordination, demonstrates the contingencies of power in determining authority in language, and performs a poetic act of resistance" (90).

Along her poetic trajectory, Brand expands her inventory of voices. This reflects the expansion of her political engagement adding to issues of gender, race and class the condition of in-betweenness of immigrants, visible minorities and others in the web of cultural differences. The ever present dialectics of origins, dilemmas of here and there, anonymous lives waiting to be accounted for are only some of the poet's motivations to persist in the art of giving voice. As she observes, "[it] / always takes long to come to what you have to say, you have to / sweep this stretch of land up around your feet and point to the / signs, pleat whole histories with pins in your mouth and guess / at the fall of words"("Land to LightOn," Vi, 12-16). More recently, her poetry expands the polyphony of urban spaces to a global scale, documenting the alliteration of violence caused by fundamentalisms, wars, and destruction of nature, marking the turn of the century. "[Keeping] watch 
at the window / of the television, she hears what is never shown, / the details are triumphant, / she'll never be able to write them in time" (Inventory, III, 116-119).

Brand's documentaries, Sisters in the Struggle and Long Time Coming', also explore the poetics of polyphony. The former brings the testimony of black women, political activists in Canada, speaking of racism and sexism in their insidious forms of permanence; the latter shows the politically engaged arts of two African-Canadian womenFaith Nolan in music and Grace Channer in visual arts-in dialogues and comments juxtaposed to music, dance and poetry. Brand's use of a plurality of voices in Sisters in the Struggle makes it possible to share individual and collective histories. As she says, in this way truth "would not be disputed." In Long Time Coming, Nolan and Channer speak of their experiences as Black lesbian, feminist artists, and the importance of giving voice to their communities. As Kate Kung notes, on Nolan's stage, "every day is Gay Pride Day," an intimacy also found in the relation between Channer's work and her community. Thus their audiences, explains Kung, "are not passive observers but full participants in their creations" (126).

Like Brand, since her early works, Obomsawin's activism is manifested in a poetics of resistance on behalf of her people. Her first documentary, Christmas at Moose Factory, makes a combination of drawings with a soundtrack of children's voices. For André Dudemaine, this documentary determined Obomsawin's way of filmmaking: "film as mouthpiece, its subjects speaking for themselves" (12). He explains that this deep respect for speech reflects Obomsawin's fidelity to the oral tradition of the Aboriginal peoples.

A landmark in Obomsawin's trajectory as filmmaker, her series of documentaries featuring the "Oka Crisis" reveal a unique quality in the polyphony of every possible angle of the conflict between Mohawks and the Canadian Government in 1990. The crisis was triggered by an act of appropriation of the Mohawks land, corresponding to their cemetery and pine reservation, to be used in the construction of luxury 
residences and a golf court. Obomsawin managed to film 250 hours during the 78 days of resistance in which she remained on the aboriginal side. The resultant documentaries, especially Kanehsatake: 270 Years of Resistance and Rocks at Whiskey Trench, show in detail the clash of voices. As Audra Simpson and Faye Ginsburg observe,

We see the complexity and confusion of the soldiers and Police (...), the variety of positions among the Euro-Canadians from leaders to laypeople (...), and the range of people who comprise registers, from experienced elders to hot-headed young men to uncomprehending children. (24)

In Kanehsatake, there is yet her voice-over narration telling the long history of land appropriation since the arrival of the colonizers. This use of archival sources and oral history ironically combines European tradition of documenting history and aboriginal tradition of orality. Unmasking official histories of the two dominant culturesFrench and English-, the narrator details how the colonizers' settlement was guaranteed at the cost of fraudulent treaties which have drastically reduced aboriginal territories. Revisionism here serves not only to disclose or rectify the past but to reveal how history continues to repeat itself. The failure of official agreements and promises for the Oka crisis recalls the old treaties. For Smaro Kamboureli, this linking of past and present "that speak at once of cultural genocide and cultural pride, of elision and perseverance" is part of a continuum persisting against "the gaps that mark the official history of Canada" (8). Another way of looking at Obomsawin's juxtaposition of past and present is considering Lee Maracle's notion of "lineage memory." She says: "To claim lineage memory and juxtapose it with current memory is to articulate the most sacred of one's entire thought from the beginning to the present and is intended as future memory" (88). Obomsawin claims this communal memory letting historical evidences speak for themselves, without intervening with judgment. In this respect, Simpson and Ginsburg note 
that Obomsawin's voice "is not the voice of God, but the voice of the engaged ally that helps the audience grasp the context and the situation that shape the events on the screen"(31).

Besides actual voices, the use of images, gestures, soundtrack, and silences in both documentaries is ingeniously articulated, turning these devices into crucial elements in the polyphony of filmic discourse. In a night scene in Kanehsatake, for example, the camera captures a mother with a child on her lap in the Mohawk's encampment. The mother is singing a lullaby in her native language and the child's eyes demonstrate fear. At the same time, a military helicopter inspects the area and a non-identified object that looks like a missile, or bomb, is shown on the ground. The juxtaposition of these images speaks for the use of an absurd force in contrast with the fragility of mother and child. A similar contrast is also shown in the snapshots of violence in Rocks at Whiskey Trench, involving civilians throwing rocks on those leaving the community for a safer place. These images evoke the persistent threat against native cultures which continue to sustain pacifist modes of behavior. The final scene of Kanehsatake reiterates this, showing the Mohawks not surrendering but pacifically leaving their front of resistance for absolute exhaustion and having to confront the unnecessary use of force on the part of the soldiers. Although Obomsawin's camera obviously privileges the cause of her people, as Ronald Wright notes, she "avoids the pitfalls of romanticizing Mohawks and demonizing whites" (35) showing divisions on both sides. Capturing a diversity of voices was certainly essential to this result.

In "Whose Gaze, and Who Speaks for Whom," discussing issues of representation and cultural appropriation, Brand comments on the saga of Blacks and aboriginal people in Canada to give voice to their histories. She says that "while some Black strategy may take on access to publishing and reviewing, some First Nation's strategy might take on the very act of saying" (126). She then discusses how "White Canada's founding meaning" must constantly prove its legitimacy, and concludes that "it is hardly surprising that First Nations people who 
contest this ownership say that no one but they should tell their stories, least of all those who benefit from the colonial conquest" (127). Obomsawin's "Cinema of Sovereignty," as Randolph Lewis calls it (156), is an effective way to reclaim this long-neglected indigenous point of view.

As Jeannette Armstrong observes, the slogan of the Oka crisis, "Protecting what is sacred," summarizes the sentiment of many Native writers, "creating an awareness of [their] unique and separate cultural realities" (xx). Obomsawin's documentaries had at the time and continue to have a vital role in perpetuating this consciousness. The proliferation of aboriginal discourses in art and politics that followed joined, so to speak, the polyphony of resistance. For Armstrong, what matters to aboriginal cultures implies voicing:

Not unrequited love and romance, not longing for motherland, not taming the wilderness nor pastoral beauty, nor driving railroad spikes nor placing the immigrant self, but [their] own collective colonized heritage of loss, pain, anger and resistance, and of [their] pride and identity as Native. (xvii)

Acknowledging the power of indigenous media, Obomsawin says that, today, more than listening to stories told by the old, aboriginal people are watching TV. She then comments on the relevance of film and education mentioning the contribution of the Aboriginal Peoples Television Network, and concludes: "That's where the power is right now. ${ }^{17}$ As mentioned in the beginning of this study, Brand too believes in the power of a multitude of voices asserting difference, not through a negative activism that, in fact, reaffirms cultural imperialism, but mainly through the potential of a transformative imagination.

Observing Brand's and Obomsawin's art works is contemplating rigorous examples of applied poetics, unique in their ethical purposes of resistance. As Fred Wah says, ethics is "something that surrounds 
our houses, it is where we live." He explains that to write (or to live) ethically (or ethnically) implies pursuing "right value, right place, right home, right otherness" (57-58). To the poet's philosophy, I would add my own instinctive response: "Yes, right poetics!"

\section{Notes}

1. Brand, "Whose Gaze and Who Speaks for Whom," 131.

2. Obomsawin's comment during a visit to the University of Hawaii at Manoa. Quoted in Berata Mita's essay "A Woman of Our Times," 15.

3. Brand interviewed by Pauline Butling, "Dionne Brand on Struggle, and Community, Possibility and Poetry," Poets Talk, 86.

4. Brand's interest in oral histories also resulted in two collections: Rivers Have Sources, Trees Have Roots: Speaking of Racism (edited with Krisantha Sri Bhaggiyadatta 1986), and No Burden to Carry: Narratives of Black Working Women in Ontario 1920's-1950 (1991).

5. Brand cited in Grammar of Dissent, 10.

6. Brand, interviewed in Poet's Talk, 85 .

7. Alanis cited in Randolph Lewis, 200.

\section{References}

Armstrong Jeannette. Introduction. Native poetry in Canada: a contemporary anthology. Eds. Jeannette Armstrong and Lally Grauer. Toronto: Broadview Press Ltd., 2001.

Brand, Dionne. "Whose Gaze and Who Speaks for Whom." Bread Out of Stone. Toronto: Couch House Press, 1994, 113-131. . Chronicles of the Hostile Sun. Toronto: Williams-Wallace Publishers, Inc., 1984. 
. Interview. "Dionne Brand on Struggle and Community, Possibility and Poetry." Poets talk: conversations with Robert Kroetsch, Daphne Marlatt, Erin Moure, Dionne Brand, Marie Annharte Baker, Jeff Derksen and Fred Wah. Eds. Pauline Butling and Susan Rudy. Edmonton: The University of Alberta Press, 2005, 67-87.

. Inventory. Toronto: McClelland \& Stuart Ltd., 2006.

. Land to Light On. Toronto: McClelland \& Stuart Inc., 1997.

. dir. Long Time Comin'. National Film Board of Canada, 1993.

. No Language is Neutral. Toronto: Coach House Press, 1990.

. Primitive Offensive. Toronto: Williams-Wallace Int'1 Inc., 1982.

. Sisters in the Struggle. Dirs. Dionne Brand and Ginny Stikeman. National Film Board of Canada,1991.

Dudemaine, André. "Portrait of the Artist as Ogima: Film and the Cause of First Nations." Alanis Obomsawin: 270 years of resistance. Montreal: The National Film Board of Canada, 2008. 10-14.

Kamboureli, Smaro. ed. Making a Difference: Canadian Multicultural Literature. Toronto: Oxford University Press, 1996.

Kung, Kate. "Long Time Comin'." Canadian Woman Studies 14: 2 (1994): 126. Available at:<https://pi.library.yorku.ca/ojs/index.php/cws/article/viewFile/9993/9097. 30 October 2009>.

Lewis, Randolph. Alanis Obomsawin: The Vision of a Native Filmmaker. Lincoln: University of Nebraska Press, 2006.

Maracle, Lee. "Skyros Bruce: First Voice of Contemporary Native Poetry." Gatherings: The En'owkin Journal of First North American Peoples 2 (1991): 85-91.

Merata, Mita. "A Woman of Our Times." Alanis Obomsawin: 270 years of resistance. Montreal: The National Film Board of Canada, 2008. 15-17.

Morrel, Carol. ed. Grammar of Dissent. Fredericton: Goose Lane Editions, 1994. 
Obomsawin, Alanis, dir. Kanehsatake: 270 Years of Resistance. National Film Board of Canada, 1993. dir. Rocks at Whiskey Trench. National Film Board of Canada, 2000.

Simpson, Audra and Faye Ginsburg. "The Oka Crisis: The power of a woman with a movie camera." AlanisObomsawin: 270 years of resistance. Montreal: The National Film Board of Canada, 2008.

Verral, Robert. "Alanis Obomsawin: singer, storyteller, filmaker, poet." Alanis Obomsawin: 270 years of resistance. Montreal: The National Film Board of Canada, 2008, 9-10.

Wah, Fred. Faking it: Poetics and Hybridity. Edmonton: NewWest Press, 2000.

Wiens, Jason. "'Language Seemed to Split in Two': National Ambivalence(s) and Dionne Brand's 'No Language is Neutral.'" Essays on Canadian Writing 70 (2000): 81-102.

Wright, Ronald. "Cutting through the razor wire at Mohawk barricades." Alanis Obomsawin: 270 years of resistance. Montreal: The National Film Board of Canada, 2008, 34-37. 